\title{
橋義歯に関する臨床的観察（1）
}

$\begin{array}{llll}\text { 戸代原孝義 } & \text { 神山 範子 } & \text { 木下 知之 } \\ \text { 中村 幸博 } & \text { 榎本 通典 } & \text { 花村 典之 }\end{array}$

\section{A Clinical study of Fixed Bridges (1)}

\author{
Takayoshi Toyohara, Noriko Kouyama \\ Tomoyuki Kinoshita, Yukihiro Nakamura \\ Michinori Enomoto and Noriyuki Hanamura
}

\section{I. まえがき}

近代的な橋義菌による補経は，1828年の Maury の橋 義歯以来改良を加えられ進歩してきた.

またその橋義歯の統計的観 察や1 5), 予後に関する調 查もなされている. 昭和 27 年に石原らは无，臨床的考察 を行っており，黒沢ら ${ }^{7}$ は，昭和 29 年に除去された架工 義歯について実態の調查を行っている. さらに尾花ら ${ }^{8)}$ は, ピンレッジによる橋義歯補緅の予後に関する臨床的 観察を行っている. 田端9,10) は, 橋義歯ダミーが歯肉に 及ぼす影響についての剝離細胞学的研究, および臨床的 観察を行っている. また竹花ら ${ }^{11)}$ は, 昭和 35〜38 年に 口腔内より歯牙と共に撤去された，冠，橋義歯に関する 臨床的考察を加えており興味深い，小島ら ${ }^{12214)}$ は, 鶴 見大学において昭和 $47 \sim 51$ 年に至る 4 年間の外来患者 に対して製作した補緅物を調查し, 比較統計観察を行っ ているが，橋義歯についても報告している.

現在, 口腔衛生思想がだんだん高まってきており，予 防,さらに補緅物のメインテナンスにも大きな注意が払 われるようになってきている. 橋義歯のダミー部につい ても最近とくに関心が持たれるようになってきたといわ れる. しかしここ15 年間位, 橋義歯の臨床的観察は報 告されていない，そこで橋義歯の現状を知るため，今回

鶴見大学歯学部補緅学教室 (主任 : 花村典之)

Department of Prosthetic Dentistry, School of Dental Medicine, Tsurumi University (chief : prof. Noriyuki Hanamura)

昭和 55 年 5 月 31 日受付
われわれは, 本学歯学部附属病院総合診断室に来院した 新来患者の口腔内を診査して, 橋義歯の装着されている 患者について臨床的観察を行い, 若干の考察を加えた. なお調査の方法は石原らの報告を参考にし, 結果につい ても比較検討をした.

調査は新来患者および急病の患者を午前中のみ診断, 治療し, 患者待機の予約などの業務を行う総合診断室に おいてなされたため, 制約があり調查人数が 100 名とな った. 今後さらに定期的に調査を行う予定である.

\section{II. 調查資料および方法}

対象は昭和 54 年 6 月 1 日より 12 月 14 日の約半年間 に鶴見大学歯学部附属病院の総合診断室を受診した患者 の 1,778 人（調查は週 1 2 回で, 合計 44 回) のうち, 橋義歯を装着していた患者 100 名を無作為に選び，協力 を要請し調查した.

口腔診査は, 問診および, ミラー, 探診, ピンセッ ト,フロスなどをもらい, 視診, 触診, 打診などを行っ た. 特に主訴の部位であり, 応急処直などの必要がある 場合を除いては原則的にX線写真による診査は行ってい ない.

調査事項は主として, 主訴が橋義歯に関するものか否 か, 口腔清掃状態, 橋義歯の部位, 構造, 装着期間, 装 着場所など. また橋義歯部位に認められる現症, たとえ ば橋義歯の破損の有無, 支台装置歯の辺縁歯肉の状態, ダミー部粘膜の状態などである. さらに現在装着されて いる橋義歯に対する患者の満足度などを調査した。 
表 1 年龄と各種調查事項

\begin{tabular}{|c|c|c|c|c|c|c|c|c|c|c|c|}
\hline & \multirow{2}{*}{\multicolumn{2}{|c|}{$\begin{array}{r}\text { 調查人員 } \\
\text { 小 } \\
\text { 計 }\end{array}$}} & \multicolumn{2}{|c|}{$\begin{array}{l}\text { 清掃 } \\
\text { 状態 }\end{array}$} & \multicolumn{6}{|c|}{ 清担回数(回) } & \multirow{2}{*}{ 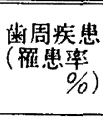 } \\
\hline & & & 可 & 不可 & 0 & 1 & 2 & $2 \sim 3$ & 3 & 4 & \\
\hline 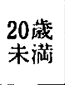 & $\begin{array}{ll}\text { 男 } & 0 \\
\text { 女 } & 2\end{array}$ & 2 & 2 & 0 & 0 & 0 & 2 & 0 & 0 & 0 & $1(50.0)$ \\
\hline $\begin{array}{l}20 \text { - } \\
29 \text { 藏 }\end{array}$ & $\begin{array}{l}\text { 令 } 5 \\
\text { 女 } 6\end{array}$ & 11 & $\begin{array}{l}2 \\
3\end{array}$ & $\begin{array}{l}3 \\
3\end{array}$ & $\begin{array}{l}0 \\
0\end{array}$ & $\begin{array}{l}2 \\
0\end{array}$ & $\begin{array}{l}2 \\
4\end{array}$ & $\begin{array}{l}1 \\
0\end{array}$ & $\begin{array}{l}0 \\
2\end{array}$ & 0 & $10(90.9)$ \\
\hline $\begin{array}{l}30 \sim \\
39 \text { 战成 }\end{array}$ & $\begin{array}{l}\text { 男 } 3 \\
\text { 女 } 25\end{array}$ & 28 & $\begin{array}{r}1 \\
10\end{array}$ & $\begin{array}{r}2 \\
15\end{array}$ & $\begin{array}{l}0 \\
0\end{array}$ & $\begin{array}{l}3 \\
6\end{array}$ & $\begin{array}{l}0 \\
8\end{array}$ & $\begin{array}{l}0 \\
2\end{array}$ & $\begin{array}{l}0 \\
8\end{array}$ & $\begin{array}{l}0 \\
1\end{array}$ & $23(82.1)$ \\
\hline $\begin{array}{l}40 \text { - } \\
49 \text { 筬 }\end{array}$ & $\begin{array}{ll}\text { 男 } & 4 \\
\text { 女 } & 17\end{array}$ & 21 & $\begin{array}{l}0 \\
5\end{array}$ & $\begin{array}{r}4 \\
12\end{array}$ & $\begin{array}{l}0 \\
0\end{array}$ & $\begin{array}{l}2 \\
5\end{array}$ & $\begin{array}{c}1 \\
10\end{array}$ & $\begin{array}{l}0 \\
0\end{array}$ & $\begin{array}{l}1 \\
2\end{array}$ & 0 & $18(85.7)$ \\
\hline $\begin{array}{l}50 \text { 一 } \\
59 \text { 藏 }\end{array}$ & $\begin{array}{l}\text { 男 } 6 \\
\text { 女 } 12\end{array}$ & 18 & $\begin{array}{l}0 \\
2\end{array}$ & $\begin{array}{r}6 \\
10\end{array}$ & 1 & 1 & $\begin{array}{l}4 \\
8\end{array}$ & $\begin{array}{l}0 \\
0\end{array}$ & 0 & 0 & $17(94.4)$ \\
\hline $\begin{array}{l}60 \text { 筬 } \\
\text { 以。: }\end{array}$ & $\begin{array}{l}\text { 男 } 12 \\
\text { 女 } 8\end{array}$ & 20 & $\begin{array}{l}2 \\
3\end{array}$ & $\begin{array}{r}10 \\
5\end{array}$ & 0 & $\begin{array}{l}7 \\
2\end{array}$ & $\begin{array}{l}4 \\
3\end{array}$ & $\begin{array}{l}1 \\
0\end{array}$ & 0 & 0 & $19(75.0)$ \\
\hline 計 & $\begin{array}{l}\text { 男 } 30 \\
\text { 女 } 70\end{array}$ & 100 & 30 & 70 & 1 & 31 & 46 & 4 & 17 & 1 & $88(88.0)$ \\
\hline
\end{tabular}

\section{III. 調查内容および結果}

\section{1. 一般的診查事項について}

1）調査患者について：調査を行った患者 100 名の内 わけは男性 30 名, 女性 70 名で，女性が 2 倍以上を占め ている. なお調査日数 44 日間の受診者総数 1,778 名の 男女比も約 $1: 2$ で女性患者が多い.なお橋義歯の装着 者すべてを調査することはできなかったので，今回の調 查で獢義歯の装着率を知ることはできない，ちなみに 昭和 27 年の石原らの報告では $26.7 \%$ であった.

年龄による分布は 20 歳末満が 2 名, 20 歳代が 11 名, 30 歳代が 28 名, 40 歳代が 21 名, 50 歳代が 18 名, 60 歳 以上が 20 名である.

2） 口腔清掃状態について：口腔全体の清掃状態の調 查は, 口腔内をみて明らかに可とするものと, 不可とす るものとの簡単な決定法で行い，とくに中性紅等で染め 出しを行うなどの調查は行わなかった. 結果は表 1 に示 すように可とするもの 30 名, 不可とするもの 70 名であ った. 男女別にみると男性で可とするもの $16.7 \%$ ，女性 で 35.7\% と女性の方が口腔清掃状態はよい，年齢別に みると， 30 歳代の女性では $40.0 \%$ が可で， 50 歳代の女 性扔よび, 60 歳以上の男性では可が $16.7 \%$ と低い值を 示した.

また清掃回数は磨かない者から，1日4回行う者まで あり，1 回の者 31 名，2回の者 46 名，3 回の者 17 名,
表 2 装着期問と各種調査事項

\begin{tabular}{|c|c|c|c|}
\hline 装着期間 & 橋義歯数 & $\begin{array}{l}\text { 破椇 数 } \\
\text { (破損率) }\end{array}$ & $\begin{array}{l}\text { 歯周疾患 } \\
\text { (眾患率) }\end{array}$ \\
\hline 半年末渾 & $5(2.9)$ & 0 & $3(60.0)$ \\
\hline 1 年 & $13(7.6)$ & 0 & $8(61.5)$ \\
\hline 2 年 & $16(9.3)$ & $7(43.8)$ & $8(50.0)$ \\
\hline 3 年 & $12(7.0)$ & $2(16.7)$ & $9(75.0)$ \\
\hline 4 年 & $6(3.5)$ & $2(33.3)$ & $5(83.3)$ \\
\hline 5 年 & $19(11.0)$ & 0 & $14(73.7)$ \\
\hline 6 年 & $13(7.6)$ & $3(23.1)$ & $10(76.9)$ \\
\hline 7 年 & $9(5.2)$ & $1(11.1)$ & $6(66.7)$ \\
\hline 8 年 & $6(3.5)$ & 0 & $3(50.0)$ \\
\hline 9 年 & $1(0.6)$ & 0 & $1(100)$ \\
\hline 10年 & $20(11.6)$ & $6(30.0)$ & $20(100)$ \\
\hline $11 \sim 20$ 年 & $25(14.5)$ & $6(24.0)$ & $18(72.0)$ \\
\hline 21年以上 & $9(5.2)$ & $9(100)$ & $7(77.8)$ \\
\hline 不明 & $18(10.5)$ & $4(22.2)$ & $10(55.6)$ \\
\hline 計 & $172(100)$ & $40(23.3)$ & $122(70.9)$ \\
\hline
\end{tabular}

2 3 回の者 4 名, 4 回の者 1 名であった. 1 日 3 回清掃 する者は女性 70 名中 16 名, 男性 30 名中 1 名の みで, 口腔清掃状態の可, 不可の結果の男女差がうなゔける.

なお歯ブラシの他にフロスを併用していたもの 1 名, ウォーターピックを併用していたもの 2 名がみられた. この 3 名を除いては特に橋義歯のダミ一部の清掃に留意 していたものはなく，歯科医，患者ともにこの部にあま り関心を持っていないことが推察できる.

3）橋義歯数等について：100 名の橋義歯装着者のう ち, 橋義歯を 1 個装着している者は 49 名， 2 個は 33 名， 3 個は 16 名, 4 個および 5 個の装着者はおのおの 1 名 で, 橋義歯総数は 172 個である.

これらの橋義歯の製作場所は, 開業医 94, 勤務先の歯 科診療室 2 , 大学病院 4 であるが, 新来患者で調査を行 ったので, 本学附属病院で製作したものはない，したが って装着時の状態は不明である.

装着期間については表 2 に示したが，半年以内のもの 5 個， 1 年までのもの 13 個， 2 年のもの 16 個， 3 年の もの 12 個, 4 年のもの 6 個, 5 年のもの 19 個と 5 年以 内のもの計 71 個 ( $41.3 \%)$ である. 6 年から 10 年まで のもの計 49 個 $(28.5 \%), 11$ 年以上 20 年までのもの 25 個 $(14.5 \%) 21$ 年以上のもの 9 個 $(5.2 \%)$, 不明のも の 18 個 (10.5\%) であった.

4）橋義歯の部位および欠損数による分類：橋義歯を 部位および欠損歯数により分類すると表 3 のようにな 
表 3 補緅部位および欠損歯数による橋義歯の頻度と破損率

\begin{tabular}{|c|c|c|c|c|c|c|c|c|c|c|c|}
\hline \multicolumn{2}{|c|}{ 部位 } & 1 & 2 & 3 & 4 & 5 & 7 & 8 & 10 & 計 & $\begin{array}{l}\text { 破抵数 } \\
\text { (破强率) }\end{array}$ \\
\hline \multirow{2}{*}{ 上 } & 前 部 & 7 & 8 & 1 & 4 & 0 & 0 & 0 & 0 & $20(11.6)$ & $7(35.0)$ \\
\hline & 白歯部 & 34 & 8 & 0 & 0 & 0 & 0 & 0 & 0 & $42(24.4)$ & $3(7.1)$ \\
\hline 顎 & 前臼歯部 & 8 & 5 & 4 & 2 & 0 & 0 & 1 & 1 & $21(12.2)$ & $6(28.6)$ \\
\hline \multirow{2}{*}{ 下 } & 前 歯 部 & 4 & 1 & 1 & 1 & 0 & 0 & 0 & 0 & $7(4.1)$ & $2(28.6)$ \\
\hline & 臼歯部 & 41 & 24 & 2 & 0 & 0 & 0 & 0 & 0 & $67(39.0)$ & $14 .(20.9)$ \\
\hline 顎 & 前臼歯部 & 5 & 4 & 1 & 2 & 2 & 1 & 0 & 0. & $15(8.7)$ & $8(53.3)$ \\
\hline \multicolumn{2}{|r|}{ 計 } & $\begin{array}{c}99 \\
(57.6)\end{array}$ & $\begin{array}{c}50 \\
(29.1)\end{array}$ & $\begin{array}{c}9 \\
(5.2)\end{array}$ & $\begin{array}{c}9 \\
(5.2)\end{array}$ & $\stackrel{2}{(1.2)}$ & $\left(\begin{array}{c}1 \\
(0.6)\end{array}\right.$ & $(0.6)$ & $(0.6)$ & 172 & $40(23.3)$ \\
\hline \multicolumn{2}{|c|}{$\begin{array}{c}\text { 破損数 } \\
\text { (破損率) }\end{array}$} & $\stackrel{23}{(23.2)}$ & $\begin{array}{l}10 \\
(20)\end{array}$ & $\begin{array}{c}4 \\
(44.4)\end{array}$ & $\begin{array}{c}2 \\
(22.2)\end{array}$ & $\left(\begin{array}{l}0 \\
0\end{array}\right)$ & $\begin{array}{c}1 \\
(100)\end{array}$ & $\left(\begin{array}{l}0 \\
0\end{array}\right)$ & $\left(\begin{array}{l}0 \\
0\end{array}\right)$ & $40(23.3)$ & \\
\hline
\end{tabular}

表 4 補緅部位および種類による支台装置の使用頻度

\begin{tabular}{|c|c|c|c|c|c|c|c|c|c|c|}
\hline \multicolumn{2}{|c|}{ 部位 種類 } & $\begin{array}{c}\text { 全部 } \\
\text { 鎕造冠 }\end{array}$ & $\begin{array}{c}\text { 帯環 } \\
\text { 金属㝴 }\end{array}$ & レジン & $\begin{array}{l}\text { 陶蒾 } \\
\text { 前装冠 }\end{array}$ & $\begin{array}{c}\text { 陶材 } \\
\text { 焼付冠 }\end{array}$ & 継続蒾 & インレー & 3/4冠 & 計 \\
\hline \multirow[t]{2}{*}{ 上 } & 前幽部 & 3 & 19 & 8 & 2 & 6 & 4 & 0 & 2 & 44 \\
\hline & 臼料部 & 25 & 53 & 7 & 0 & 1 & 0 & 0 & 0 & 86 \\
\hline 諬 & 前臼㐘 & 11 & 45 & 5 & 0 & 2 & 0 & 0 & 1 & 64 \\
\hline \multirow[t]{2}{*}{ 下 } & 前幽部 & 0 & 8 & 2 & 0 & 4 & 0 & 3 & 0 & 17. \\
\hline & 臼蒌部 & 32 & 90 & 6 & 0 & 0 & 0 & 0 & 3 & 131 \\
\hline 顎 & 前E溇部 & 3 & 35 & 5 & 0 & 0 & 0 & 1 & 1 & 45 \\
\hline \multicolumn{2}{|c|}{ 計 $(\%)$} & $74(19.1)$ & $250(64.6)$ & $33(8.5)$ & $2(0.5)$ & $13(3.4)$ & $4(1.0)$ & $4(1.0)$ & $7(1.8)$ & 387 \\
\hline \multicolumn{2}{|c|}{ 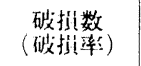 } & $\begin{array}{c}4 \\
(5.4)\end{array}$ & $\begin{array}{c}44 \\
(17.6)\end{array}$ & $(6.1)$ & 0 & 0 & 0 & 0 & $\begin{array}{c}3 \\
(42.9)\end{array}$ & $\begin{array}{c}53 \\
(13.7)\end{array}$ \\
\hline
\end{tabular}

る. ただし前歯部とは両側犬歯間を指し， 臼歯部は第 1 小臼歯より後方, 前臼歯部とはこの両者にわたるもので ある.

上額におけるもの 83 個 (48.3\%), 下顎におけるもの 89 個 (51.7\%) であるが，下䫅臼歯部におけるものが 最も多く $39.0 \%$ を占めている. 次いで，上顎臼歯部 $(24.4 \%)$ ，上頡前臼歯部 (12.2\%) 上頭前歯部 (11.6\%) とつづき，下頡前臼歯部 (8.7\%)，下顎前歯部 (4.1\%) は少ない.これは石原らの報告とほとんど同じ傾向を示 している.

また遊離端橋義歯も 23 個あり，前歯部 1 個，白歯部 16 個, 前臼歯部 6 個となっている. 石原らの報 告では 遊離端橋義歯が $9 \%$ を占め, これを補緅学的に特殊なも のとして部位に関係なく一括したが，われわれの報告で は特に区別していない.

欠損歯数 (ダミーの数) により分類すると，1歯欠損 を補緅したものが圧倒的に多く，57.6\%を占め，2歯を
補綴したものは $29.1 \% ， 3$ 歯，4歯を補綴したものがお のおの $5.2 \% ， 5$ 歯を補緅したものが 2 個で $1.2 \% ， 7$ 歯，8齿，10歯を補経したものが 1 個ずつあり，8歯， 10 歯を補緅したものは遊離端橋義歯であった. 1〜2歯 を補綴したものが大部分を占め，5歯以上になると極端 に少なくなっているのがわかる.

5）支台装㯰の種類について : これは表 4 に示すよう に全部鋳造冠, 帯環金属冠, レジン前装冠, 陶歯前装 冠, 陶材焼付冠, 継続歯, インレー, 3/4 冠がみられ, 二重金冠によるなどの可撤橋義歯はみられなかった.

全支台装置 387 個のうち帯環金 属 冠によるものが $64.6 \%$ を占め, 全部鋳造冠によるものが $19.1 \%$, レジン 前装冠 $8.5 \%$, 陶歯前装冠は $0.5 \%$, 陶材焼付冠 $3.4 \%$,

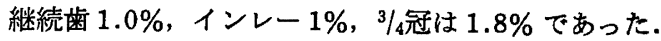

ここ 10 年以内に製作された橋義歯が, 120 個と $69.8 \%$ を占めているにむかかわらず, 全部鋳造冠の使用頻度は 少なく，部位にかかわらず，圧倒的に帯環金属冠が多 
補緅誌 24 巻 3 号 (1980)

表 5 補緅部位および材料，形態によるダミーの使用頻度

\begin{tabular}{|c|c|c|c|c|c|c|c|c|c|c|c|}
\hline \multicolumn{2}{|c|}{ 部位 材料 } & 陶 材 & レジシ & 金 属 & 計 & 部位 & 鞍状型! & $\begin{array}{l}\text { 完全 } \\
\text { 自浄型 }\end{array}$ & 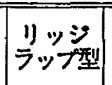 & 偏側型 & 有床型 \\
\hline \multirow[t]{2}{*}{ 上 } & 前丵部 & 10 & 24 & 1 & 35 & 前㧘部 & 15 & 0 & 7 & 10 & 3 \\
\hline & 白㐘部 & 0 & 35 & 16 & 51 & 日菌部 & 36 & 5 & 7 & 7 & 0 \\
\hline 顎 & 前臼㐘部 & 1 & 36 & 20 & 57 & 前曰歯部 & 45 & 0 & 1 & 9 & 2 \\
\hline \multirow[t]{2}{*}{ 下 } & 前拳部 & 4 & 7 & 4 & 15 & 前畨 部 & 8 & 0 & 1 & 4 & 2 \\
\hline & 曰菌部 & 0 & 54 & 25 & 79 & 白歯部 & 67 & 9 & 0 & 3 & 0 \\
\hline \multirow[t]{2}{*}{ 哿 } & 前臼菌部 & 1 & 32 & 8 & 41 & 前臼㐘部 & 27 & 2 & 0 & 6 & 6 \\
\hline & 計 & $16(5.8)$ & $188(67.6)$ & $74(26.6)$ & 278 & 計 & $198(71.2)$ & $16(5.8)$ & $16(5.8)$ & $35(12.6)$ & $13(4.7)$ \\
\hline
\end{tabular}

（）内は\%

い.しかし今までの報告にはほとんどみられなかったい わゆる前装鋳造冠が $12.4 \%$ も使われているのは注目に 值する. 継続歯, インレー, 3/4冠によるものはほとんど なく数\%にすぎない.

な找昭和 $49 \sim 51$ 年の本学附属病院に扔ける橋義 歯 支 台装置の統計によると,支台装置 1,200 個のうち, 陶材焼 付冠によるもの $10.9 \%$ ，全部鋳造冠によるもの $78.9 \%$, レジン前装冠によるもの $4.8 \% ，$ インレー $0.2 \%$ ，継続 歯 $0.3 \%$ であったが，今後は審美性ということにより前 装冠によるものが，一般に多く用いられるものと思われ る.

6）ダミーについて：ダミー部の基底 面材料は，表 5 に示寸ように，陶材，レジンおよび金属が用いられて いる. 全ダミー 278 個のうち, レジンが $67.6 \%$ を占め 圧倒的に多く，金属によるもの $26.6 \%$, 陶材によるもの $5.8 \%$ と少ない。

部位別に材料の使用 頻度をみると，上滪前歯は 35 個 中，陶材 10 個 (28.6\%) で，レジン 24 個 (68.6\%), 金 属は 1 個（2.9\%）のみである.上頡臼歯部では陶材を使 用しているものはなく， 51 個中,レジン 35 個 (68.6\%), 金属 16 個（31.4\%）である. 上效前臼歯部では 57 個中， 陶材 1 個 (1.8\%)，レジン 36 個 (63.2\%), 金属 20 個 (35.1\%) である. 下滪前歯部では， 15 個中，陶材 4 個 (26.7\%), レジン 7 個 $(46.7 \%)$, 金属 4 個 $(26.7 \%), 下$ 頻臼歯部は，上頻同様陶材は使用されておらず,79 個中， レジン 54 個 (68.4\%)，金属 25 個（31.6\%）である, また下額前臼歯部では， 41 個中, 陶材 1 個 (2.4\%), レ ジン 32 個 $(78.0 \%)$ ，金属 8 個 (19.5\%) である.

ダミーの形態に関しては, 鞍状型 $(71.2 \%)$, 完全自 浄型 $(5.8 \%)$, リッジラップ型 $(5.8 \%)$, 偏側型 (12.6 \%), 有床型 (4.7\%) がみられ, 鞍状型が大部分を占め
ている.

部位により形態をみると，上頻前歯部では，鞍状型 $42.9 \%$, リッジラップ型 $20.0 \%$, 偏側型 $28.6 \%$ で, 有床 型 $8.6 \%$ である. 上頡臼歯部では, 鞍状型 $70.6 \%$ を占め, 完全自浄型も $9.8 \%$ みられ，偏側型 $5.9 \%$ である. 上顥 前臼歯部も鞍状型が多く，78.9\% となっている. 下顎

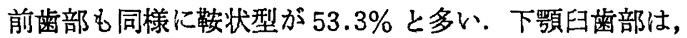
鞍状型が最も高い值を示し $84.8 \%$ となっている. 完全 自浄型がこの部位の最も適応しやすい形態であるにもか かわらず, $11.4 \%$ を占めるにすぎない．偏側型も $3.8 \%$ みられる.下䫟前臼歯部は鞍状型 $65.9 \%$, 完全自 浄型 $4.9 \%$ ，偏側型，有床型ともに $14.6 \%$ である.

橋義歯のダミー部に関して最もよい材料とされている 陶材は $5.8 \%$ しか用いられておらず，あまり好ましくな いとされているレジンが $67.6 \%$ を占め, しかも，これ も好ましくないとされている鞍状型の形態によるものが $71.2 \%$ もの高率を占めているということは，この部に対 する考虑が十分払われているとは決していえない。

\section{2. 橋義歯に関する主訴および現在の橋義歯に対する 満足度について}

橋義歯装着患者 100 名のうち，主訴が橋義歯に関する ものは 24 名で, 残りの 76 名は他の部位に関するもので あった．橋義歯に関する主訴をもつもので，支台歯の疼 痛を訴えたものが 9 名, 破折を訴えたものが 6 名, 支台 歯およびダミー部の歯肉の出血, 排膿を訴えたもの 3 名, 橋義歯の動摇を訴えたもの 3 名, この他食片の圧入 を訴えたもの，橋義歯が仮着状態であると訴えたもの， 審美的理由で前歯部橋義歯の再製作を希望したもの各 1 名であった.

また主訴が橋義歯に関するものでなくても，現在の橋 
義歯に満足しているかとの質問に何らかの不満を訴え， 満足していないと答えたものは 32 名あった. 結局 100 名のうち 66 名は現在装着されている橋義歯に対して不 満をいだいていた.

\section{3. 橋義歯に関する所見}

1）歯頸部マージンの適合性について：固定性補叒物 の予後を左右する1つとして, 補経物と支台歯の適合性 があげられる，橋義歯に関しても支台装置の適合がよく ないということは，歯髄疾患，歯周疾患の大きな原因と なっている. 全支台装置 387 個について歯頸部マージン の適合性について診查を行い，明らかに可とするむの と, 不可とするものの判定を行った. 適合性の良し悪し の判断は大きな問題であるが，今回は目安として歯質と 補緅物との間に探診が入るものを不可とした. 結果につ いては可としたもの 106 個 (27.4\%)，不可としたもの， 281 個 (72.6\%) であった。

マージンを歯頸部に適合させることが難しい帯環金属 冠の使用頻度が多いこと，また部分被覆冠が支台装置と して使用されることが少なく，マージンを縁下に設定す ることが多、全部被覆冠による支台装置がほとんどであ ることがこの結果を生じさせていると思われる ${ }^{15)}$.

2）破損について：橋義歯の破損を主訴として来院し た患者は 6 名であったが, ダミー部のレジン脱落, 咬合 面の穿孔のための泠水痛など患者が容易に自覚できるも のであった. また橋義歯自体の脱落も 1 例あった. 全体 として破折等の訴えは少なく，全支台装置 387 個中，小 穿孔等, 破損と認められるものは 53 個 (13.7\%) であ った. 部位によりこれをみると上顎前歯部 13 , 上狉臼歯 部 10 , 下頡前歯部 8 , 下䫑臼歯部 22 となっている. な お支台装置の位置により計算しているので，前臼歯部と いら分類はない.

破損がみられた支台装置の，種類による破損率は，表 4 亿示したが帯環金属冠が $17.6 \%, 3 / 4$ 冠は $42.9 \%$, 全 部鋳造冠 $5.4 \%$ ，レジン前装冠 $6.1 \%$ で，帯環金属冠， $3 / 4$ 冠の破損率が高く, 全部鋳造冠, レジン前装冠は少な かった. これは帯環金属冠, $3 / 4$ 冠はその構造上他の鋳造 冠等に比べて強度が劣ることを示している.

橋義歯単位としては, 支台装置が 2 個以上破折してい るものもあるので 40 個 (22.3\%) に破損がみられた. これを橋義歯の装着期間のわかっている 82 個について みると 36 個に破損がみられ，表 2 に示したようにな る. 装着期間 5 年間においての破損率は 71 個中 11 個で $15.5 \%$ である. 次の 5 年間における破損率 は $20.4 \%$,
11 年から 20 年における破損率は $24 \%, 21$ 年以上になる と 9 個すべてに破損がみられ，長期間使用したものに破 損率が高くなっている.

これを部位別にみると，表 3 に示したように，破損率 は上額前歯 $35 \%$ ，上頻臼歯 $7.1 \%$ ，上效前臼歯 $28.6 \%$, 下額前歯 $28.6 \%$, 下頻臼歯 $20.9 \%$ ，下顯前臼歯 $53.3 \%$

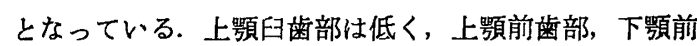
臼歯部は高い值を示している.

また欠損歯数によりこれをみると，破損率は 1 歯欠損 を補緅したものが $23.2 \% ， 2$ 歯欠損では $20 \% ， 3$ 歯欠損 では $44.4 \%, 4$ 歯欠損では $22.2 \%$ であった. 7 歯欠損を 補緅したものは 1 個あるがこれには破損がみられた. 5 , 8, 10 歯欠損では破損はみられなかった. 3 歯欠損で $44.4 \%$ と高率を示したが, 万う着部が破損するなどの大 きな例はみられず，橋脚の穿孔等の破損が主であるの で， 欠損歯数と大きな関連はみられないように思える.

3）橋義歯と歯周疾患：歯周疾患が橋義歯の予後と密 接な関係をもつことはいうまでもないが，石原らは，歯 周疾患を根尖性のものと, 辺縁性のものとに分類して調 査した. すなわち瘦孔, 腫脹, 根尖部圧痛等の症状のあ るものを根尖性歯周疾患を持つ橋義歯とし，また辺縁歯 肉の発赤, 腫脹, 出血, 排膿㧍よび歯牙動摇等の症状の あるものを辺縁性歯周疾患を持つ橋義歯とした.

今回われわれも 172 個の橋義歯につきこれらの症状の 有無を観察した. なお症状の軽重をとわず，支台装置歯 1 個にでも症状の認めたものを菌周疾患に罹患している ものとした.

根尖性歯周疾患の症状が認められた者は 24 名,橋義歯 数 25 個 (14.5\%) であった. この 25 個の橋義歯はすべ て辺縁性歯周疾患の症状も併せもっていた，根尖性歯周 疾患は補緅処置以前の保存治療の良否と関係が樑く, $\mathrm{X}$ 線診断も行っていないのでこのことには深くふれない．

橋義歯部に歯周疾患を認めた者は 88 名で, 橋義 歯総 数 122 個 (70.9\%) である.

i）年齢と歯周疾患：各年代別に罹患率を表 1 に示し たが，いずれの年代も高率を示している. 20 歳未満の 50 $\%$ から， 60 歳以上の $95 \%$ となっている.

ii）装着期間と歯周疾患：これについては表 2 に示す 通りであるが，装着期間 5 年までのもの 71 個に対して 47 個 (66.2\%) に歯周疾患がみられ，6〜10 年までの 49 個に対して 40 個 (81.6\%), それ以上のもの 34 個に対 して 25 個 (73.5\%) といずれも高率を示しているが, 最初の 5 年間に括けるものは以後のものに比して䍜患率 は低い。 
表 6 補緅部位および欠損歯数による歯周疾患の頻度

\begin{tabular}{|c|c|c|c|c|c|c|c|c|c|c|}
\hline \multicolumn{2}{|c|}{ 部位 } & 1 & 2 & 3 & 4 & 5 & 7 & 8 & 10 & 計(䍜然率) \\
\hline \multirow{2}{*}{ 上 } & 前 部 & 7 & 8 & 1 & 2 & & & & & $18(90.0)$ \\
\hline & 臼迷 部 & 25 & 6 & & & & & & 1 & $31(73.8)$ \\
\hline 顎 & 前臼歯部 & 6 & 4 & 4 & 2 & & & 0 & & $17(81.0)$ \\
\hline \multirow[t]{2}{*}{ 下 } & 前 类 部 & 3 & 0 & 1 & 1 & & & & & $5(71.4)$ \\
\hline & 白 歯 部 & 26 & 14 & 2 & & & & & & $42(62: 7)$ \\
\hline 顎 & 前臼㴹部 & 2 & 2 & 1 & 2 & 1 & 1 & & & $9(60)$ \\
\hline \multicolumn{2}{|c|}{ （瞿㭧率） } & $\begin{array}{c}69 \\
(69.7) \\
\end{array}$ & $\begin{array}{c}34 \\
(68)\end{array}$ & $\begin{array}{c}9 \\
(100)\end{array}$ & $\begin{array}{c}7 \\
(77.8)\end{array}$ & $\begin{array}{c}1 \\
(50)\end{array}$ & $\begin{array}{c}1 \\
(100)\end{array}$ & $\begin{array}{l}0 \\
(0)\end{array}$ & $\begin{array}{c}1 \\
(100)\end{array}$ & $\begin{array}{c}122 \\
(70.9)\end{array}$ \\
\hline
\end{tabular}

表 7 ダミーおよびダミー部粘膜の状態

\begin{tabular}{|c|c|c|c|c|c|c|c|c|c|}
\hline \multicolumn{2}{|c|}{ 部位 } & 沈洋物 & 発 “赤 & 着 色 & 出 监 & 腫 脹 & 圧 痛 & 瘦 孔 & ダミー数 \\
\hline 上 & 前齒部 & $21(91.3)$ & $15(65.2)$ & 0 & 0 & $9(39.1)$ & 0 & 0 & 23 \\
\hline 哿豆 & 曰嵝部 & $41(80.4)$ & $19(37.3)$ & $7(13.7)$ & $2(3.9)$ & $18(35.3)$ & $2(3.9)$ & 0 & 51 \\
\hline 下 & 前歯部 & $9(81.8)$ & $5(45.5)$ & $1(9.1)$. & $1(9.1)$ & $3(27.3)$ & 0 & 0 & 11 \\
\hline 哿i & 曰渎部 & $41(68.3)$ & $22(36.7)$ & $6(10)$ & $1(1.6)$ & $18(30.0)$ & $1(1.7)$ & 0 & 60 \\
\hline & 郭 & $112(77.2)$ & $61(42.1)$ & $14(9.7)$ & $4(2.8)$ & $3(33.1)$ & $3(2.1)$ & 0 & 145 \\
\hline
\end{tabular}

iii） 橋義歯の部位, 久損歯数と歯周疾 患: 部位捄よ び欠損数による分類は表 6 に示した. 全体に高率を示し ているが，下顎前臼歯部の罹患率が一番低く $60.0 \%$ ，次 いで下䫑臼歯部の $62.7 \%$ と続き，上額前臼歯部の 81.0 $\%$ と高くなり，上頡前歯部の $90.0 \%$ と最高の値を示し ている.

また久損歯数に関しては，1歯欠損 $69.7 \%, 2$ 歯欠損 $68.0 \%$ と霍患率は低いが, 補経歯数が多いほど,支台装置 歯に加わる負担が大きくなるためか高率を示している.

年龄，装着期間，部位，欠損蒾数々歯周疾患の関係を 検討したが，橋義歯 172 個のうち 122 個（70.9\%）に歯 周疾患がみられるため，いずれの䍜患率も高いものとな っている. これらは装着時の状態が不明なこと, 支台装 㯰歯以外の歯について歯周疾患の調査を行っていないこ と，また支台装置歯 1 個にでも症状があると，その橋義 歯部は歯周疾患ありとして算定したため高い罹患率を示 していることなどで，すぐに橋義歯装着の歯周疾患䍜患 率が高いとは結論できないが，石原らの調査において橋 義歯非装着者の菌周疾患䍜患率が $25 \%$ 内外であること より，やはりかなりの高率であることはわかる.

また辺縁性歯周疾患と関倸が深い歯垢, 歯石等, 沈着
物について，全橋脚について観察したが，236 個（61.1 \%）に沈着物がみられた.

2）ダミー部について：ダミー部のダミー，および粘 膜について沈着物, 発赤, 着色, 出血腫脹, 圧痛, 瘦孔 の有無に関して診查を行った. これは橋義歯 172 個のう ち 140 個についての結果である.

欠損歯数にかかわらず，ダミーが連続している場合は 1 つのダミー部とし，離れている場合は別に算定したの で計 145 カ所にっいて診查を行っている．ダミー部の位 置している部位により，上，下顎前歯部および臼歯部の 分類とした. ダミーが前臼歯部にまたがる場合は，その 位置を多く占める部位とした. 結果は表 7 に示した通り である. 沈着物はすべての部位について高率を占め, 上顎前歯部 $91.3 \%$, 上說臼歯部 $80.4 \%$, 下顎前歯部 $81.8 \%$ ，下頒臼歯部はやや少なく $68.3 \%$ にみられた.

発赤は順に $65.2 \% ， 37.3 \% ， 45.5 \% ， 36.7 \%$ にみら れた. 出血がみられたのは意外に少なく，上䫓臼歯部 $3.9 \%$, 下頡前歯部 $9.1 \%$, 下影臼歯部 $1.6 \%$ で, 全体で は $2.8 \%$ であった. しかし，われわれは日常臨床でよく 経験するのであるが，外見からは一見何でもないように みえる橋義歯でも，ダミーを除去するとその部にび闌， 
圧痕，出血がみられることが多く，今回の調查における 出血とはあくまでも橋体の外側からの観察である. 出血 にはいたらないが腫镺が認められたものは順に $39.1 \%$ ， $35.3 \% ， 27.3 \% ， 30.0 \%$ とかなりの率を占めている. 圧 痛が認められたのは，上，下買臼歯部にそれぞれ1例ず つであった. 瘦孔はみられなかったが，本来欠損してい る部位で残根を認めたものが 1 例あった.

ダミーの基底面は本来清掃しにくい所であり，ほとん どこの部に関心が向けられていなかったが，污れの状態 と出血傾向を診查するためフロスを通過させてみた. 使 用フロスは, Educational Health products 社のスーパ ーフロスである.これは先端が細くややかたくなってお り, 軟かく太い部分が続き, 細くなって終わっている.

太い部分もしくは細い部分が通過できるかどうかとい うことと，さらに一往復させたあと橋体部粘膜に出血が みられるかどうか, またフロスの污れの状態を 3 段階(き れい. 污れている. 著しく污れている.) に区分した.

全ダミー部 177 カ所について診查したが，結果は，太 い部分がスムーズに通過したもの 143 , 細い部分がかろ うじて通過したもの 7 , 患者が痛みを訴えてフロスを通 過させることができなかったもの 27 であった.フロス が通過した場合についてフロスに血液が付着したもの， すなわちフロスを通過させることによって出血したもの は60であり，出血しなかったもの90であった. ダミー 部粘膜に出血を認めたものは $2.8 \%$ であったが, この結 果より,ダミー部粘膜に出血傾向を持つ者が多いといえ る.フロスが通過しなかった 27 についても出血する可 能性が大であるからさらに出血する率は増えると思われ る.

このフロスに歯垢が付着してきたものがあったが， きれいであったもの $86(57.3 \%)$, 污れていたもの 58 (38.7\%), 著しく污れていたもの6 $(4.0 \%)$ であった. なおフロスを使用していた患者およびウォーターピック を使用していた患者はともに出血も，フロスの污れも認 められなかった.

この結果によれば，污れがほとんどなかったものが $57.3 \%$ とダミー下が清潔である者が多い上うな印象を うけるが, 沈着物が $77.2 \%$ に認められたことや, ダミ 一下の沈着物が歯石になっていることが多いためフロス に付着しにくかったように思えること，またダミーの形 態が鞍状型で凹面を持っている部位の污れはフロスでは なかなかとるのが困難であることなどより，実際には， そんなに清潔ではない、いずれにせよダミー部の状態は 清掃の面からしても決して良好な状態にあるとはいえな
い.なお本学附属病院においては,この部の清掃指導を 行っており，良好な結果を得ていることをつけ加えてお く.

\section{総括および結論}

最近の橋義歯の予後に関する臨床的観察の報告を塞開 にして知らない，われわれは今回橋義歯の現状の一端で も把握することを目的として，本学歯学部附属病院に来 院した新来患者のうち, 橋義歯を装着していた 100 名に ついて，172 個の橋義歯を診查した. すでに報 告されて いる結果と比較して,ここ15 年間位の間に橋義歯の現 状が大きく改善されているとは思えず，決して良好な状 態にあるとはいえない，特にダミー部に対する考慮がほ とんどなされていないことで，口腔衛生思想の普及はい まだしの感がした，以下本調查における結論を記す。

1）支台装置として，帯環金属冠が依然として多く使 用されている，使用頻度は少ないが全部鋳造冠む使用さ れるようになっている．また前装鋳造冠がみられるよう になっている. 継続歯, 部分被覆冠によるものは極端に 少ない.

2）ダミー部基底面は，材料としてレジンによるもの が多く $(67.6 \%)$, 形態も鞍状型 $(71.2 \%)$ が多く採用 され，清掃にも関心が向けられていず，考慮が十分払わ れているとは, 決していえない.

3） 100 名の橋義歯装着者の5ち 66 名は現在装着さ れている橋義歯に満足していなかった.

4）支台装置の歯頸部マージンの適合状態 は $72.6 \%$ が不良と判断され, 二次う蝕, 歯周疾患の原因となり得 る.

5）破損は大きなものはほとんどみられず，咬合面部 の小穿孔等が主なものであった.

6）橋義歯装着者 100 名中 88 名に橋義歯部に歯 周 疾 患が認められた. 全橋義歯 172 個のうち 122 個(70.9\%) の橋義歯部に歯周疾患が認められた.

7）以上の点より，われわれが診查した橋義歯の予後 の状態は満足すべきものではなく，歯科医，患者共に， 補緅物に対する認識をより高めるよう心掛けなければな らないと思われる。

\section{文献}

1) 中沢勇：諸種補綴物の統計的観察, 齿科学雑誌， $1: 21$, 1944. 
2) 中沢勇, 岡四郎: 戦前, 戦後の諸種補緅物の比较統計観 察, お茶の水学会誌, $1: 47,1949$.

3) 中沢勇, 中村光雄: 諸種補緅物の比較統計的観察（第 3 報), 口病誌， $20: 136,1953$.

4）中沢勇, 平沼謙二, 小沢至, 富士川善彦：諸種補緅物の 比較統計的観察(4), 口病誌, $26: 360,1959$.

5）井上昌幸, 佐藤敏郎, 花村典之, 児林三代, 鈴木康夫： 諸種補経物の比較統計的観察(5), 口病誌.

6）石原寿郎，尾花甚一，平沼謙二：橋義歯の予後に関する 臨床的考察, 口病誌, $23: 75,1956$.

7）黒沢正二, 菊池博：除去された架工義歯の実態, 補緅誌, $1: 84,1957$.

8）尾花甚一, 飛奈達也, 橋本鿁, 富士川善彦：ビソレッヂ による橋義雷補緅の予後に関する臨床的観察, 補緅誌, $2: 99,1958$.

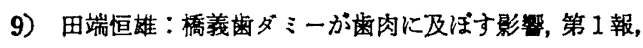
剶離細胞学的親察, 口病誌, $29: 24,1962$.

10）田端桓雄：橋義崡ダミーが歯肉に及ぼす影敏, 第 2 報, 臨床的観察, 口病誌, $29: 375,1962$.

11）竹花庄治, 吉川潔, 安江高根, 藤田直輝, 川上舜子, 宮 田潤一：歯牙と共に撤去された冠，橋義歯に関する臨床 的考察, 補緅誌, $7: 132,1963$.

12）小島秀夫, 関純男, 花村典之: 諸種補経物の比較統計的 観察 I, 鶴見崡学, $1: 77,1975$.

13）小島秀夫, 関純男, 花村典之：諸種補緅物の比較統計的 観察 II, 鶴見歯学, 1:83, 1975.

14）雅山秀夫, 梅本智代, 佐藤阿里子, 花村典之：諸種補経 物の比較統計的観察III, 鶴見齿学, $3: 121,1977$.

15）戸代原孝義, 花村典之：支台装置の選択, 歯界展望, 55： $617,1980$. 